\title{
ПОЛІТОЛОГІя
}

УДК 32:342.553-027.581

DOI https://doi.org/10.32837/apfs.v0i27.934

\author{
Д. І. Антонюк \\ ORCID ID: https://orcid.org/0000-0002-3143-4464 \\ аспірант кафедри політології та державного управління \\ Чернівецького національного університету імені Юрія Федьковича
}

\section{ОСНОВНІ КРИТЕРІЇ ЛЕГІТИМАЦІЇ ПУБЛІЧНИХ ОРГАНІВ ВЛАДИ НА МІСЦЕВОМУ РІВНІ}

Формування довіри до органів влади посідає чільне місце у легітимації влади загалом та політичного режиму зокрема. Успішна взаємодія між місцевим населенням та органами місцевої влади, що базується на довірі, на наш погляд, буде ключовим фактором під час налагодження співпраці останніх із закордонними інституціями, що в контексті глобалізації буде показником успішності реформи децентралізації у сучасній Україні, тому дослідження критеріїв легітимації публічних органів влади на місцевому рівні дасть змогу чітко визначити пов'язані з цим проблеми та вирішити їх.

Дослідженням теоретичної основи легітимності займались як зарубіжні класики (Мартін Сеймур Ліпсет) [4], так і сучасні дослідники (Жан-Марк Куако) [14], що дає змогу цілісно визначити основу поняття. Безпосередньо дослідженням процесів легітимаціїорганів влади на місцевому рівні займалися скандинавські дослідники Пер Петтерсен [17], Катаріна Роос, Андерс Лідстрем [16]. 3 огляду на демократичні процеси в органах місцевого самоврядування, що відбуваються під впливом глобалізації, актуалізується проблема формування довіри до влади на локальному рівні за сучасних умов, тому постає завдання виокремлення критеріїв і чинників її легітимації, що є метою нашого дослідження.

Під легітимацією зазвичай розуміють складний комплексний процес досягнення легітимності, який характеризують як визнання населення права на управління [14, с. 10]. Враховуючи особливості місцевого рівня, що характеризується виборністю та організаційною відокремленістю органів місцевого самоврядування в загальній системі органів управління суспільства з власною самостійною економічною основою діяльності, для досягнення мети нашого дослідження вважаємо доцільним використати два взаємопов'язані і взаємозалежні типи легітимності місцевої влади (К. Роос, А. Ліндстрем), а саме зовнішньої та внутрішньої, для яких можна виокремити критерії легітимації. Зовнішня легітимність місцевої влади безпосередньо залежить від виконання нею покладених функцій управління, отже, одну з ключових ролей у іiї легітимації відіграє належна підтримка нею локальної інфраструктури [16, с. 137]. Спроможність місцевої влади підтримувати належний стан інфраструктури зазвичай оцінюється за результатами управління комунальною власністю; підтримання у належному стані доріг, парків, зон відпочинку; формування належного водопостачання, транспортного сполучення тощо. Якщо жителі громади не мають нарікань на роботу комунальних служб та рішень місцевої ради щодо удосконалення благоустрою населеного пункту, то найвірогідніше, що податки, які надходять до місцевого бюджету, використовуються за призначенням, а не осідають у кишенях місцевої еліти. Це дуже важливий показник, особливо в умовах децентралізації [17, с. 62]. Науковці Університету Умео (Королівство Швеція) провели опитування мешканців декількох шведських міст і визначили, що легітимність влади на локальному рівні насамперед залежить саме від належної підтримки інфраструктури. Критерії, що стосуються можливостей громадського впливу на прийняття політичних рішень і здійснення громадського контролю, були оцінені дещо нижче, однак науковці пояснили це тим, що більшість громадян Швеції не мали досвіду втручання в роботу органів місцевого самоврядування, бо цілком задоволені якістю надання владою послуг, однак при цьому зауважується, що без наявності каналів громадського впливу не було би відповідного результату. На нашу думку, наявність розвиненої інфраструктури та ефективність управління нею органами місцевої влади перш за все впливає на її легітимацію, проте в суспільствах, що розвиваються, наявність каналів впливу на місцеву владу є критично необхідною, що не просто попереджує руйнацію ефективності управління, але й елементарно стимулює ії до виконання своїх прямих обов'язків [16, с. 143-144].

Саме наявність ефективних каналів контролю за діяльністю публічної влади на місцевому рівні є основою її внутрішньої легітимності. Контроль 
суб'єктів управління насамперед має здійснюватися з боку громадськості. До того ж під впливом глобалізації на фоні демократичних процесів, в тому числі на місцевому рівні, гостро постає питання налагодження належної взаємодії між інститутами влади та громадянським суспільством [3, с. 13]. Відомий американський політолог М.С. Ліпсет визначає таку співпрацю продуктом легітимності, тому якщо на місцевому рівні між органами влади та громадськістю вона відсутня, то можна робити відповідні висновки [6]. Нині в Україні діє низка законів [9-12], що містять деякі положення щодо взаємодії громадян із місцевою владою, однак об'єктивно цього недостатньо для забезпечення широкої участі громадськості у соціально-політичному житті свого регіону. Натомість протилежна ситуація спостерігається у сусідній Польщі, де успішно діють спеціалізовані закони, угоди, рішення, що регламентують співпрацю між органами місцевого самоврядування та громадськими організаціями задля вироблення якісної місцевої політики [1, с. 94]. Регулярна i, що головне, результативна співпраця місцевої влади з громадянським суспільством у рамках вжиття заходів із покращення добробуту населеного пункту або цілого регіону говорить про взаємну довіру, що заснована на спільних цілях і цінностях, тому, на нашу думку, виступає одним із критеріїв легітимації публічної влади на локальному рівні $[14$, с. 14, 40].

Залучення нових технологій до місцевого управлінського процесу задля налагодження швидкої взаємодії з громадськістю також може слугувати одним із критеріїв легітимації. Можливість подання електронних петицій є серйозним чинником формування довіри до органів місцевого самоврядування. Завдяки їй громадяни можуть безпосередньо зазначити локальні проблеми, які, на їхню думку, потребують вирішення. Такі звернення встановлюють певний взаємозв'язок між представниками суспільства та представниками влади, що може говорити про певний рівень довіри між ними [8]. 3 іншого боку, подання петицій щодо скасування прийнятих рішень свідчить про протилежне. Так, низка рішень Чернівецької міської ради викликала негативний резонанс у громадськості та в подальшому призвела до поразки на виборах представників партій, що їх ухвалювали. Наприклад, рішення про надання земельної ділянки для будівництва каплиці на площі Пресвятої Марії викликало здебільшого негативну реакцію у громадськості, а петиція про скасування рішення за 2 дні набрала необхідну кількість голосів [13]. Отже, показник кількості поданих петицій за скасування прийнятих рішень можна вважати делегітимаційним критерієм.

Громадський контроль є ключовим інструментом громадянської оцінки виконання органами влади їх зобов'язань і виступає одним з основоположних правових засад легітимації влади. На міс- цевому рівні одними з найефективніших механізмів громадського контролю є громадські ради та громадські слухання. Громадські ради при органах місцевого самоврядування покликані сприяти врахуванню цими органами громадської думки під час підготовки та прийняття рішень; вносити пропозиції та рекомендації щодо роботи органів місцевої влади; здійснювати нагляд за станом виконання програм розвитку територіальної громади тощо [7]. Натомість громадські слухання виступають механізмом громадської участі, за якого жителі громади можуть вносити свої пропозиції та зауваження щодо питань місцевого значення, які належать до відання органів місцевого самоврядування. Порядок ініціювання, підготовки, проведення громадських слухань і врахування їх результатів у нашій державі регулюються Законом України «Про місцеве самоврядування в Україні» (ст. 13) [11] та статутами територіальних громад, однак саме такий стан речей створює перешкоди для функціонування цього інституту на певних територіях, адже залишається ризик не включення положень про організацію громадських слухань у статути територіальних громад або в інші локальні документи, що так чи інакше потребують затвердження рішеннями місцевих рад. Хоча для європейського суспільства залучення до процесу ухвалення рішень представників громадянського суспільства є нормальною практикою, бо їх участь є гарантією того, що прийняте рішення буде ефективним і отримає загальну підтримку, недосконалість вітчизняного законодавства може звести нанівець ефективність цього механізму.

Ще одним показником довіри до місцевої влади є забезпечення її публічності. Як показує практика, громадський контроль на місцевому рівні не $є$ ефективним без прямої участі засобів масової комунікації. Задля того, щоби забезпечити легітимність своїх дій, владі необхідно налагодити постійний діалог із представниками суспільства. 3 іншого боку, засоби масової комунікації можуть сприяти делегітимації місцевої влади, тому в інтересах місцевої еліти не створювати зайвих негативних інфоприводів, а сконцентруватися на підвищенні рівня довіри з боку громадськості, доносячи до неї об’єктивну інформацію. Представники влади можуть інформувати суспільство через участь у прес-конференціях, офіційні заяви, виступи на інформаційних площадках тощо. Наприклад, донедавна на телеканалі «Чернівці» виходила в ефір телепередача «Три запитання меру», в якій очільник міста відповідав на питання громадськості, що надходили до редакції телеканалу протягом тижня. Важливим також $є$ те, як публічні органи влади звітують місцевому населенню про виконану роботу через власні сучасні канали поширення інформації, зокрема офіційні веб-сайти, Facebook-сторінки, Telegram-канали. На основі цього громадськість має можливість 
проаналізувати завдання й цілі, які ставила перед собою влада, визначити їх доцільність та виправдання очікувань [2, с. 94].

Отже, на легітимність органів публічної влади на місцевому рівні насамперед впливають їх спроможність та ефективність виконання покладених обов'язків, зокрема, щодо підтримки належного стану локальної інфраструктури. Однак, на наш погляд, ключове значення має можливість здійснення впливу на діяльність місцевих органів влади, адже без стороннього нагляду реалізація інтересів місцевої громади перебуває під загрозою, бо владні можливості високопосадовців починають працювати на їх особисту користь. Несприятливою ситуація є й тоді, коли інструменти контролю на локальному рівні все ж таки існують, але є неефективними або непопулярними серед місцевого населення, що проявляється у делегітимаційних процесах. Зокрема, така ситуація спостерігається у м. Чернівці, де тривалий час (від початку обрання на відповідну посаду у 2014 році) спостерігали деструктивне протистояння Чернівецького міського голови Олексія Каспрука та секретаря міської ради Василя Продана й очолюваної ним фракції «Рідне місто», внаслідок чого не було вчасно прийнято багато необхідних для ефективного функціонування міста рішень. Цей конфлікт - чудовий приклад того, як протистояння персоналізованих інтересів має негативний ефект для добробуту міста, адже через взаємну критику та звинувачення важко оцінити ефективність роботи посадовців. Як наслідок, згідно з офіційними результатами місцевих виборів 2019 року в Чернівецькій області, О. Каспрук, єдиний із чинних тоді очільників міст, не потрапив до другого туру виборів, а політична сила В. Продана ледве подолала бар'єр у 5\% і завела до Чернівецької міської ради лише трьох депутатів $(7,14 \%$ від загального складу Ради) [6] проти десяти (23,81\%) порівняно з результатами 2015 року [5]. Про нетерпимість місцевих жителів до політичних протистоянь у стінах місцевих органів влади свідчить несподіваний успіх щойно створеної місцевої політичної партії із символічною назвою «Єдина Альтернатива» на тих же виборах до Чернівецької міської ради [8], що під час своєї передвиборної кампанії уособлювала сподівання чернівчан на припинення політичних чвар і корупції.

Відповідно до чинного українського законодавства [11], посада міського голови, як і посада депутата міської ради, є виборною, тому взаємне несприйняття послаблює політичні позиції обранців в очах виборців, порушує ідею політичного представництва на місцевому рівні, а в цьому разі фактично дискредитує Чернівецьку міську раду загалом. Причиною цього може слугувати невідповідний тип політичної культури українського суспільства, адже в Данії, що славиться ефективним управлінням на місцевому рівні та низьким рівнем корупції серед місцевої еліти, особиста репутація та похідна від неї довіра є цінним надбанням, що спрощує ведення справ у всіх аспектах суспільного життя [15]. Завоювання довіри місцевими елітами безпосередньо залежить від створення ними так званої репутації надійних партнерів, тобто такої, що гарантує місцевому населенню неупереджену, злагоджену та своєчасну реакцію на його потреби, де влада виступає як «виробник послуг», а громадськість - як «клієнт». Якщо суб'єкти вироблення послуг через особистісні причини не в змозі виконувати своїх функцій, «клієнти» шукатимуть їм заміну [18, с. 253-254], тому наявність конфліктних взаємовідносин між представниками місцевої еліти разом із відсутністю співпраці та координації дій підриває не тільки ефективність здійснення ними посадових обов' язків, але й їх легітимність.

Окремо наголосимо на принциповій важливості ефективної антикорупційної діяльності для легітимації місцевої влади. Корупція разом із особистісними конфліктами між високопосадовцями підриває ефективність місцевих органів влади, натомість управлінський потенціал використовується для задоволення приватних інтересів, чим автоматично порушує принцип політичного представництва на локальному рівні. Завадити цьому, на наш погляд, перш за все може активне громадянське суспільство. Зазвичай на місцевому рівні питання корумпованості місцевої владної еліти перевірити та піддати суспільному розголосу простіше, однак можуть нівелюватися інші фактори викривальницької діяльності, зокрема конфіденційність, безпека. Це знову ж говорить про принципове значення побудови розвинутого громадянського суспільства для вироблення ефективної антикорупційної діяльності, відсутність якої щільно вкорінює корупцію у сферу владних відносин, тому низький рівень корупції є важливим показником як ефективності, так і легітимності місцевої влади [3, с. 8].

Отже, у табл. 1 наводимо основні критерії легітимації публічних органів влади (ПОВ) на місцевому рівні відповідно до запропонованого підходу визначення легітимності (за К. Роос та А. Ліндстремом).

Основні критерії легітимації публічних органів влади (ПОВ) на місцевому рівні

\begin{tabular}{|c|c|}
\hline Зовнішня легітимність & Внутрішня легітимність \\
\hline $\begin{array}{c}\text { Виконання ПОВ своїх } \\
\text { прямих зобов'язань }\end{array}$ & $\begin{array}{c}\text { Ефективна взаємодія/співпраця } \\
\text { влади із суспільством }\end{array}$ \\
\hline & Громадський контроль ПОВ \\
\hline & Антикорупційна діяльність \\
\hline & $\begin{array}{c}\text { Залучення нових технологій для } \\
\text { удосконалення взаємозв'язку } \\
\text { «влада - суспільство» }\end{array}$ \\
\hline & Забезпечення публічності ПОВ \\
\hline
\end{tabular}


Отже, на легітимність місцевої влади впливають як іï власна результативність і ефективність виконання нею своїх повноважень, так і інші фактори, що потребують активного залучення громадянського суспільства для стимулювання й контролю за владними органами. Зокрема, впровадження дієвих механізмів антикорупційного та громадського контролю, забезпечення публічності публічних органів влади через ефективну роботу 3MI та ЗМК, залучення сучасних технологій для координації владою дій із суспільством аж до плідної співпраці в контексті виконання спільних проєктів для підвищення якості місцевої політики сформують належну довіру до локальних органів влади, тому водночас виступають критеріями їх легітимації. Натомість недосконале вітчизняне законодавство й слабкий розвиток громадянського суспільства можуть послаблювати вплив вищезазначених критеріїв, паралельно формуючи небажані корупційні ризики та підриваючи локальну політичну стабільність, що говорить про взаємозв'язок досягнення легітимності місцевими публічними органами влади та інших процесів загального розвитку.

\section{Jimepamypa}

1. Антонюк Д. Легітимаційні аспекти антикорупційної діяльності неурядових організацій Польщі: досвід для України. Влада та управління : збірник наукових праць. Вип. 7. Чернівці : Букрек, 2020. С. 88-98.

2. Гавінська О. Легітимаційний потенціал взаємодії органів публічної влади та засобів масової комунікації на місцевому рівні. Наукові праці Чорноморського державного університету імені Петра Могили комплексу «Києво-Могилянська академія». Серія: Державне управління. 2012. Т. 208. Вип. 196. С. 91-95. URL: http://nbuv.gov.ua/UJRN/Npchdu_2012_208_196_19 (дата звернення: 13.12.2020).

3. Коваль О. Легітимність державної влади: співвідношення правових і моральних аспектів реалізації : автореф. дис. ... канд. юрид. наук : спец. 12.00.01. Львів, 2017. 19 с. URL: http://ena.lp.edu. ua:8080/bitstream/ntb/39522/1/Avtoref_Koval.pdf (дата звернення: 22.01.2021).

4. Липсет С. Размышления о легитимности. URL: http://pavroz.ru/lipset-legitimacy (дата звернення: 7.07.2020).

5. Місцеві вибори 25 жовтня 2015 року. Загальні відомості про результати голосування. Чернівецька обл., Чернівецька міська рада. URL: https://web. archive.org/web/20151112070255/http://www.cvk. gov.ua $/$ wvm $2015 /$ pvm 057 pid $112=30$ pid $102=1848$ pf 7 $691=1848 \mathrm{pt001 \textrm {f } 0 1}=100 \mathrm{rej}=0 \mathrm{pt00} \_\mathrm{t} 001 \mathrm{f} 01=100 \cdot \mathrm{html}$ (дата звернення: 8.01.2021).

6. Місцеві вибори 25 жовтня 2020 року. Загальні відомості про результати голосування. Чернівецька обл., Чернівецька міська рада. URL: https://www.cvk.gov. $\mathrm{ua} / \mathrm{pls} / \mathrm{vm} 2020 / \mathrm{pvm} 057 \mathrm{pid} 112=30 \mathrm{pid} 102=1848 \mathrm{pf} 769$ $1=64721 \mathrm{pt} 001 \mathrm{f} 01=695 \mathrm{rej}=0 \mathrm{pt00} \_\mathrm{t} 001 \mathrm{f} 01=695 . \mathrm{html}$ (дата звернення: 8.01.2021).

7. Положення про Громадську раду при виконавчому комітеті Чернівецької міської ради. URL: http:// chernivtsy.eu/portal/polozhennya-pro-gromadsku-radu (дата звернення: 10.08.2020).

8. Про внесення змін до Закону України «Про звернення громадян» щодо електронного звернення та електронноїпетиції:ПояснювальназапискаПроєктуЗакону від 3 березня 2015 року. URL: http://w1.c1.rada.gov.ua/ pls / z web $2 /$ webproc 34 ? id = \& pf $3511=54267 \&$ pf35401=332218 (дата звернення: 11.08.2020).

9. Про доступ до публічної інформації : Закон України від 13 січня 2011 року № 2939-VI. URL: https://zakon.rada.gov.ua/laws/show/2939-17 (дата звернення: 11.08.2020).

10.Про звернення громадян : Закон України від 2 жовтня 1996 року № 393/96-BP. URL: https://zakon2.rada.gov.ua/laws/show/393/96 $\%$ D0\% B2\% D1\% 80 (дата звернення: 11.08.2020).

11. Про місцеве самоврядування в Україні : Закон України від 21 травня 1997 року № 280/97-ВР. URL: https://zakon.rada.gov.ua/laws/show/280/ 97-\% D0\% B2\% D1\% 80 (дата звернення: 11.08.2020).

12.Про порядок висвітлення діяльності органів державної влади та органів місцевого самоврядування в Україні засобами масової інформації : Закон України від 23 вересня 1997 року № 539/97-ВР. URL: https://zakon.rada.gov.ua/laws/show/539/97$\%$ D0 \% B2\% D1\% 80 (дата звернення: 13.12.2020).

13. Скасування рішення щодо будівництва каплиці (церкви) посеред площі Пресвятої Марії. URL: https://e-dem.in.ua/chernivtsi/Petition/ View/1445 (дата звернення: 13.12.2020).

14. Coicaud J.-M. Legitimacy and Politics: A Contribution to the Study of Political Right and Political Responsibility. Cambridge University Press. 2002. 259 p. DOI: https://doi.org/10.1017/CBO9780511490200.

15. Collier P. How to change cultures of corruption. URL: https://www.gov.uk/government/publications/ against-corruption-a-collection-of-essays/againstcorruption-a-collection-of-essays \# paul-collier-howto-change-cultures-of-corruption (accessed: 19.06.2020).

16. Roos K., Lidstrm A. Local policies and local government legitimacy. The Swedish case. Urban Research \& Practice. 2014. № 7 (2). P. 137-152. DOI: $10.1080 / 17535069.2014 .910920$.

17. Rose L., Pettersen P. The legitimacy of local government - What makes a difference? Evidence from Norway. Citizen Responsive Government. 2000. Vol. 8. P. 25-65. DOI: https://doi.org/10.1016/ S1479-3520(00)80006-9.

18. Rose-Ackerman S., Palifka B. J. Corruption and Government: Causes, Consequences, and Reform. Cambridge University Press. 2016. 618 p. DOI: https://doi.org/10.1017/CBO9781139962933.

\section{Анотація}

Антонюк Д. І. Основні критерії легітимації публічних органів влади на місцевому рівні. - Стаття.

У статті автор розглядає умови та критерії легітимації публічних органів влади на місцевому рівні. 3 огляду на особливості місцевого рівня управління у статті використано підхід із двома взаємозалежними типами легітимності для подальшого визначення критеріїв легітимації. Зокрема, на прикладі скандинавських країн визначено особливості та риси зовнішньої легітимності 
місцевих органів влади. Відповідно, визначено значення та сутність внутрішньої легітимності для досягнення належної ефективності влади на місцевому рівні. Розкрито взаємозв'язок досягнення владою внутрішньої легітимності та здійснення контролю за їі діяльністю. Також на прикладі Польщі проаналізовано значення співпраці місцевої влади з громадськістю для досягнення загальної довіри та легітимності. Розкрито значення залучення сучасних технологій, таких як системи подання електронних петицій, задля налагодження ефективної комунікації «влада - суспільство» для розвитку легітимаційних та попередження делегітимаційних процесів. Проаналізовано роль громадського контролю для вдосконалення системи прийняття локальних рішень та легітимізації влади загалом. Також обгрунтовано велике значення забезпечення публічності органів місцевої влади як одного з критеріїв легітимності для здійснення якісного контролю за їх діяльністю та попередження виникненню процесів делегітимації.

На прикладі конфронтації чернівецької політичної еліти зображено негативний вплив протистояння персоналізованих інтересів на електоральну підтримку та добробут міста загалом. Також запропоновано поширену в розвинутих країнах модель взаємовідносин «місцева влада - суспільство», де основу складає високий рівень культури, що базується на незаплямованій особистісній репутації, тому виокремлюється ще один критерій легітимації місцевої влади, а саме антикорупційний контроль, що покликаний забезпечити ефективність влади через попередження корупційних ризиків та збереження локальної політичної стабільності.

Таким чином, визначено, що до основних критеріїв легітимації публічних органів влади належать виконання ними своїх повноважень; забезпечення ефективних механізмів антикорупційного та громадського контролю за їх діяльністю; ефективна робота $3 \mathrm{MI}$ та ЗMК, що висвітлюють їх діяльність; залучення нових технологій взаємодії з громадськістю; виконання спільних програм, проєктів для підвищення якості місцевої політики.

Ключові слова: легітимність, легітимація, критеpiї легітимації місцевої влади, антикорупційна діяльність.

\section{Summary}

Antoniuk D. I. Basic criteria for legitimation of public authorities at the local level. - Article.

In the article the author considers the conditions and criteria for the legitimation of public authorities at the local level. Given the peculiarities of the local level of government, the article uses an approach with two interdependent types of legitimacy to further define the criteria of legitimacy. In particular, the peculiarities and features of the external legitimacy of local authorities have been identified on the example of the Scandinavian countries. Accordingly, the importance and essence of internal legitimacy for achieving proper efficiency of government at the local level is determined. The relationship between the government's achievement of internal legitimacy and control over its activities is revealed. Also, on the example of Poland, the importance of cooperation between local authorities and the public to achieve general trust and legitimacy is analyzed. The importance of involving modern technologies, such as electronic petition submission systems, in order to establish effective communication "government - society" for the development of legitimation and prevention of delegitimization processes is revealed. The role of public control for improving the system of local decision-making and legitimizing the government in general is analyzed. Also, the importance of ensuring the publicity of local authorities, as one of the criteria of legitimacy, for the implementation of quality control over their activities and prevention of delegitimization processes is substantiated.

The example of the confrontation of the Chernivtsi political elite shows the negative impact of the confrontation of personalized interests on electoral support and the welfare of the city as a whole. Also, a model of the relationship "local government - society", which is widespread in developed countries, is proposed, where the basis is a high level of culture based on an unblemished personal reputation. Therefore, another criterion of legitimation of local government is singled out - anti-corruption control, which is designed to ensure the effectiveness of government by preventing corruption risks and maintaining local political stability.

Thus, it is determined that the main criteria for the legitimation of public authorities include: their performance of their powers; ensuring effective mechanisms of anti-corruption and public control over their activities; effective work of the media and media, covering their activities; involvement of new technologies of interaction with the public; implementation of joint programs, projects to improve the quality of local policy.

Key words: legitimacy, legitimation, criteria of legitimation of local government, anti-corruption activity. 